\title{
Pelatihan dan Perbaikan Website Sebagai Media Promosi Sarasvita FCJ Center
}

\author{
Rudolfo Rizki Damanik ${ }^{1}$, Robin ${ }^{2 *}$ \\ ${ }^{1,2}$ Program Studi Informatika, Fakultas Ilmu Komputer, Universitas Pelita Harapan, Medan, Indonesia \\ Email: ${ }^{1}$ rudolfo.damanik@uph.edu, ${ }^{2}$ robin.huang@lecturer.uph.edu
}

\begin{abstract}
Technology has cause society to work efficiently and it has also enabled information to be gained easily. Technology has also helped society in information distribution, knowledge distribution and promotion. One of many information technology used for promotion is website. Rumah Retreat Sarasvita (Sarasvita FCJ Center) is a retreat center located in Yogyakarta where previeusly the retreat already has a website to promote their information about retreat and meditation information to citizen. However, the website was developed using old web technology framework which causing not all information can be deliver easily. To solve this problem, the website feature must be improve and other features have to be added periodically. The aim to improve the website is to help more people to find inner peace through the website. The Sarasvita FCJ Center was still actively give us feed back even until the time this article was written for each feature developed causing the website requirement can be easily matched until Sarasvita satisfied of the feature development.
\end{abstract}

Keywords: Sarasvita, Retreat Center, Retreat House, Meditation.

\begin{abstract}
Abstrak
Teknologi telah membantu banyak umat manusia dalam hal efisiensi pekerja dan mendapatkan sebuah informasi. Teknologi juga membantu manusia dalam hal penyebaran informasi, pengetahuan dan pemasaran atau promosi. Salah satu teknologi informasi yang dapat digunakan untuk promosi adalah website. Rumah Retreat Sarasvita (Sarasvita FCJ Center) adalah sebuah retreat center yang beralamat di Yogyakarta dimana sebelumnya Rumah Retret Sarasvita sudah menggunakan website sebagai media bantu dalam hal penyebaran informasi mengenai retret dan meditasi kepada masyarakat. Namun, karena website tersebut sebelumnya dikembangkan dengan menggunakan teknologi web yang lebih awal sehingga tidak semua informasi dapat disajikan dalam bentuk yang lebih baik. Untuk mengatasi hal tersebut dibutuhkan adanya pengembangan ataupun perbaikan fitur yang tentunya harus direvisi (maintenance) secara berkala. Tujuan revisi dan pengembangan website Rumah Retret Sarasvita adalah agar dapat membantu lebih banyak orang untuk menemukan inner peace melalui website Rumah Retret Sarasvita ini. Pihak Rumah Retret Sarasvita juga berperan aktif dalam setiap proses dan capaian setiap fitur dari pengembangan dan maintenance terhadap website tersebut sehingga requirement dari pihak Sarasvita dapat dicapai dengan mudah dan hingga pada akhirnya Rumah Retert Sarasvita menyetujui dan merasa puas atas hasil pengembangan dan maintenance Website Sarasvita FCJ Center.
\end{abstract}

Kata Kunci: Sarasvita, Retret Center, Rumah Retret, Meditasi.

\section{A. PENDAhULUAN}

Perkembangan teknologi telah membantu banyak umat manusia dalam hal efisiensi pekerja dan mendapatkan sebuah informasi. Teknologi dipandang hal yang penting dan tidak bisa dilepaskan dalam kehidupan sehari - hari. Perlahan pekerjaan manusia sangat tergantung dalam teknologi informasi, dimana jika pekerjaan itu dilakukan secara manual maka bisa dipastikan pekerjaan tersebut memakan waktu yang lama. Teknologi juga membantu manusia dalam hal penyebaran informasi dan pengetahuan, jika di era belum adanya teknologi maka informasi itu memakan waktu berbulan - bulan agar dapat diketahui oleh orang lain. Salah satu teknologi informasi adalah internet dan web. Internet adalah jaringan komunikasi elektronik yang menghubungkan jaringan komputer dengan fasilitas komputer di seluruh dunia dan web merupakan salah satu layanan yang disajikan melalui internet.

Di zaman sekarang web telah banyak membantu manusia dalam hal penyebaran informasi, tidak sampai disitu saja manusia melihat website juga sebagai ajang untuk melakukan kegiatan bisnis. Hal ini pula 
yang mendorong banyak perusahaan ataupun organisasi dalam memanfaatkan media website sebagai alat untuk memberitahukan kepada khalayak ramai terkait informasi dan kegiatan yang dilakukan oleh perusahaan ataupun organisasi. Rumah Retret Sarasvita yang beralamat di Yogyakarta menggunakan website sebagai media bantu dalam hal penyebaran informasi retret dan meditasi kepada masyarakat. Tujuan mereka adalah membantu orang untuk menemukan inner peace. Adapun website yang sedang berjalan belum mampu memberikan informasi yang akurat dikarenakan tim pengelola website masih terbatas dalam pengetahuan IT.

Pengetahuan yang minim tentang pemrograman web oleh Staff Rumah RetRet Sarasvita membuat website tersebut tidak pernah dilakukan pembaharuan secara berkala, hal ini pula yang mendorong Staff Rumah RetRet Sarasvita untuk meminta bantuan kepada penulis dan tim dalam hal perbaikan. Perbaikan yang dilakukan oleh penulis adalah memperbaiki tampilan website yang telah dibangun menggunakan wordpress, membuat manual book terkait penggunaan dan pembaharuan data yang ada di website dan memberikan training secara berkala pada Staff Rumah RetRet Sarasvita.

Pendahuluan berisi tentang latar belakang dilakukannya kegiatan pengadian masyarakat oleh dosen/ mahasiswa/ dosen yang melibatkan mahasiswa/ praktisi/ industri. Pendahuluan terdiri dari beberapa paragraf yang dimulai dari fenomena/masalah yang terjadi, latar belakang tim pengabdian melakukan kegiatan pengabdian, tujuan kegiatan pengabdian, manfaat kegiatan pengabdian serta beberapa publikasi terdahulu terkait kegiatan pengabdian yang pernah dilakukan oleh tim pengabdian sebelumnya (apabila ada).

\section{B. PELAKSAAN DAN METODE}

Kegiatan Pengabdian kepada Masyarakat ini dilakukan secara online, adapun Rumah RetRet Sarasvita Yogyakarta berada di Condong Catur Yogyakarta. Kegiatan ini dilakukan mulai dari 4 Oktober 2021 sampai dengan 23 Desember 2021.

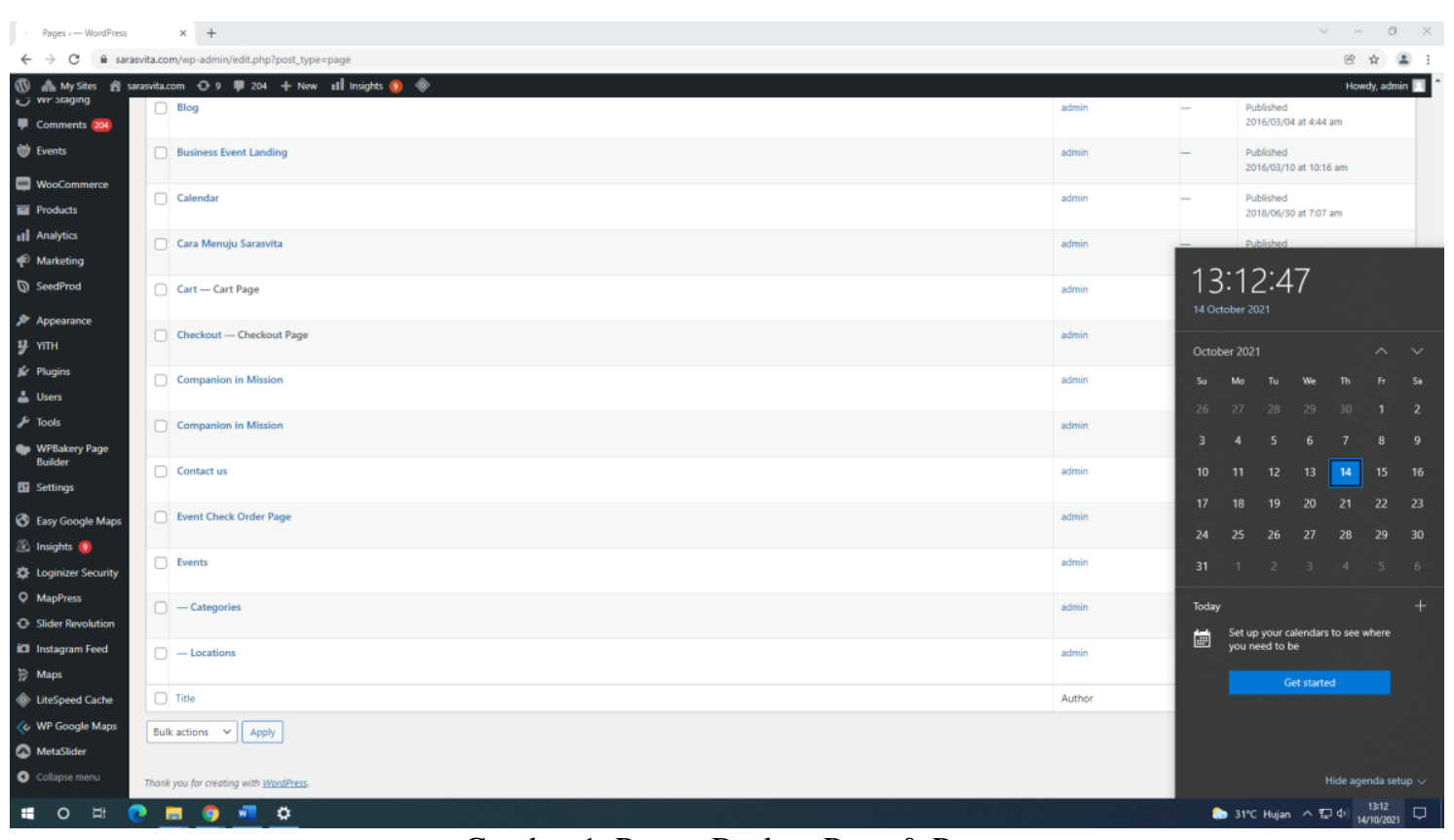

Gambar 1. Proses Backup Page \& Post

Pada tahap ini tim melakukan proses backup terhadap page dan post dengan tujuan jika ada file page dan post yang rusak selama proses perbaikan maka dengan cepat bisa dikembalikan seperti semula. 


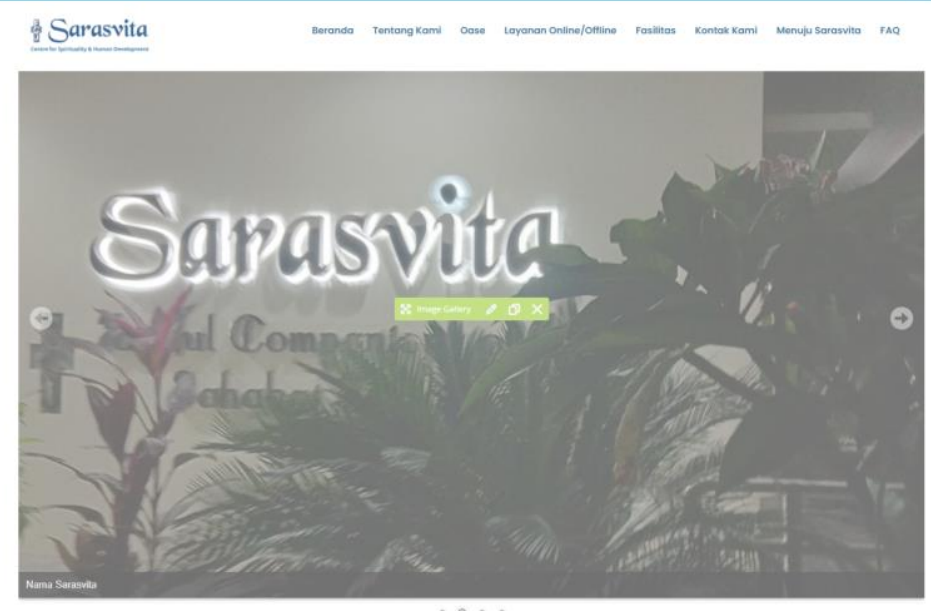

Gambar 2. Proses perbaikan tampilan dan update informasi

Pada tahap ini tim melakukan perbaikan sesuai dengan arahan yang diberikan oleh Staff Rumah RetRet Sarasvita. Tim melakukan perbaikan terhadap susunan Menu, Nama Menu, Sub Menu dan konten yang ada sehingga dapat memberikan informasi yang up-to-date kepada visitor web.
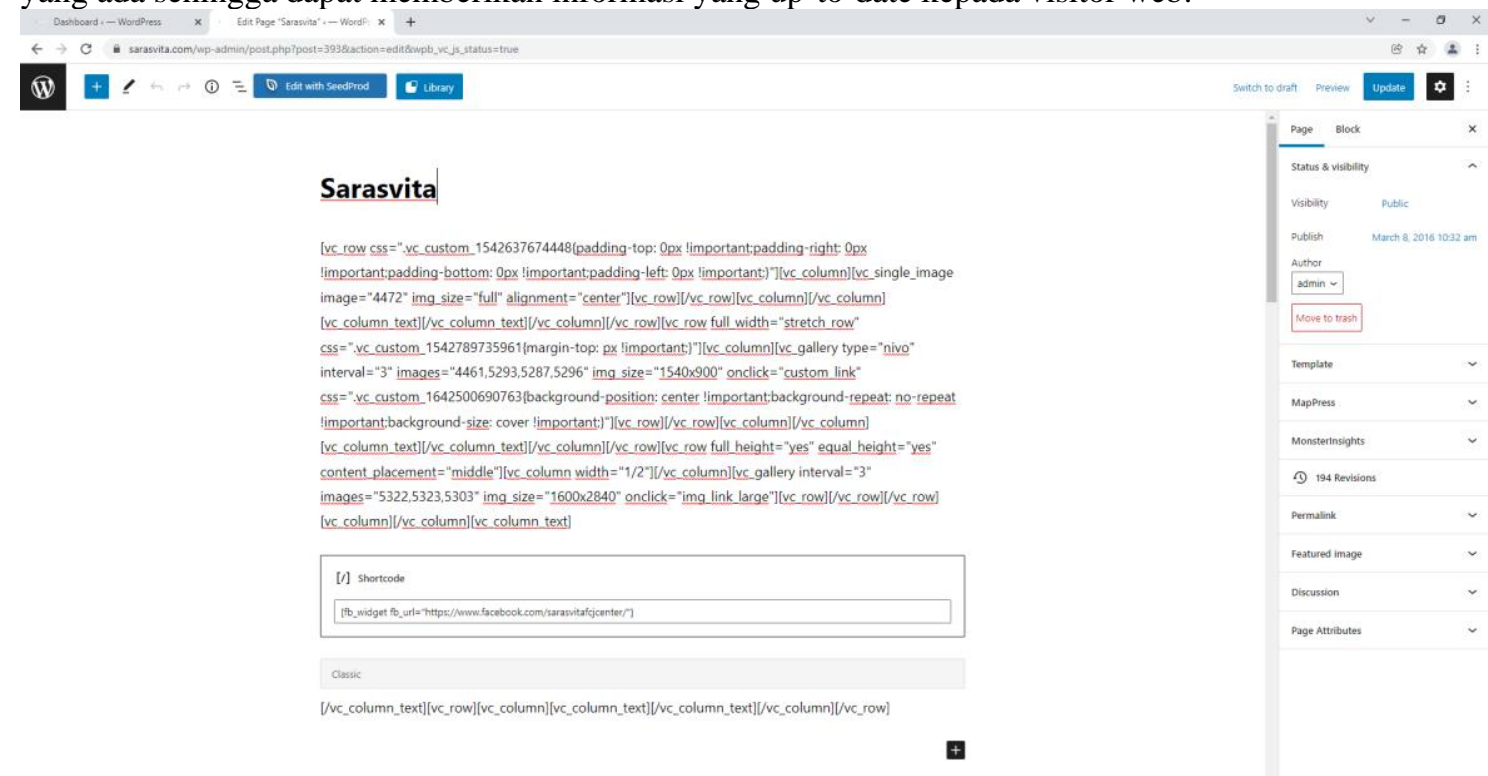

Gambar 3. Perbaikan dari sisi tag HTML

Penulis dan tim melakukan perbaikan dari sisi code/tag HTML hal ini dikarenakan fitur WPPageBuilder tidak memberikan keleluasaan dalam hal perbaikan tampilan. Sehingga kami memperbaiki tampilan menggunakan tag HTML seperti pada CSS dan Javascript agar web lebih interaktif dan menarik.

\section{HASIL DAN PEMBAHASAN}

\section{Cara Login ke WP Admin Sarasvita}

1. Buka link berikut: http://sarasvita.com/wp-admin 
2. Maka akan muncul tampilan seperti ini setelah di buka.

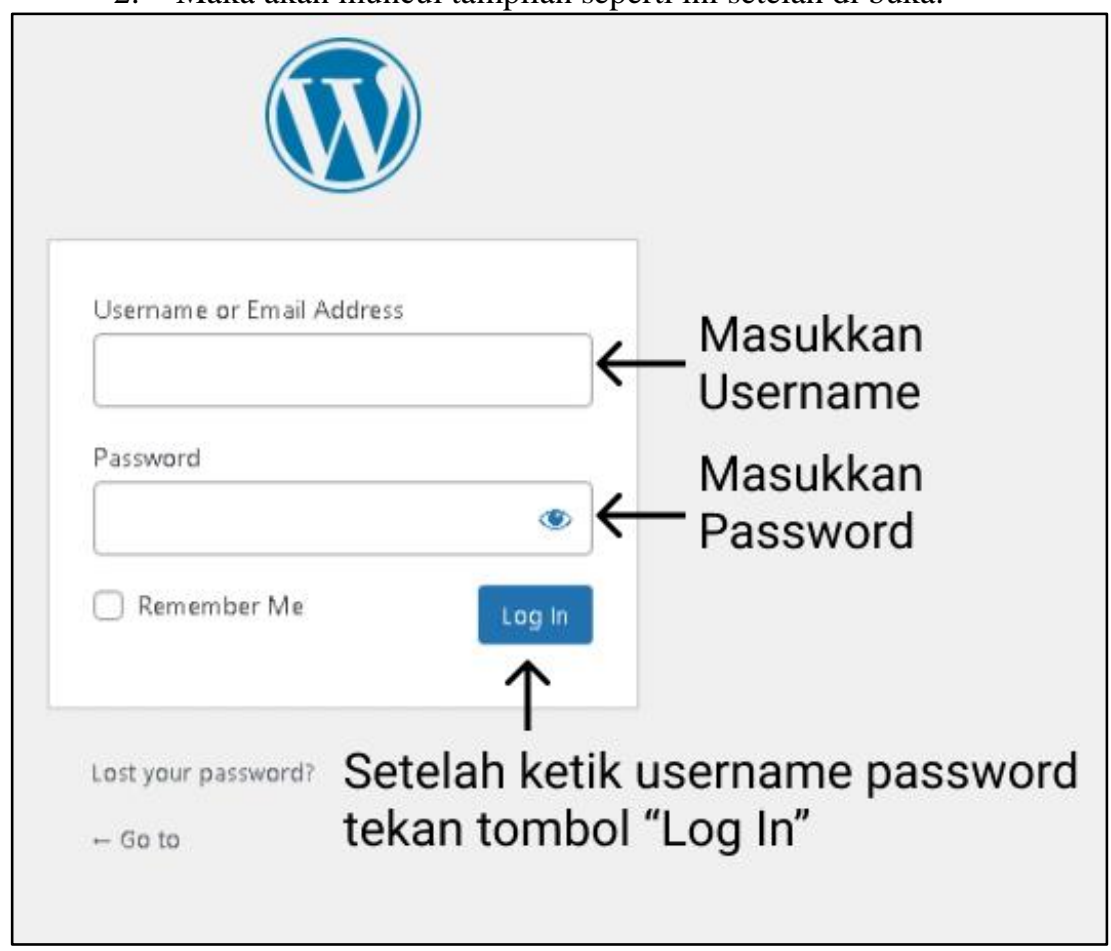

Gambar 4. Tampilan Login

3. Masukkan username dan password setelah itu tekan tombol "Log In". Jika sudah berhasil Login maka akan keluar seperti ini.

\begin{tabular}{|c|c|c|c|}
\hline \multicolumn{4}{|c|}{ 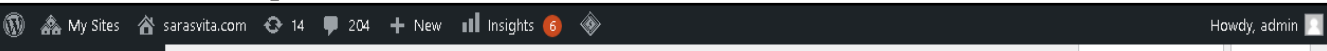 } \\
\hline Dashboard & \multicolumn{3}{|l|}{ Dashboard } \\
\hline $\begin{array}{l}\text { Home } \\
\text { My Sites }\end{array}$ & \multicolumn{3}{|l|}{ A Google Maps Al key is required. Please update your Mappress Settings. } \\
\hline Insights & \\
\hline t Posts & \multicolumn{3}{|c|}{$\begin{array}{l}\text { Monsternsights, Wordpress analytics plugin, helps you connect your website with Google Analytics, so you can see how people find and use your website. Over } 3 \text { million } \\
\text { website owners use Monsternsights to see the stats that matter and grow their business. }\end{array}$} \\
\hline 魚 IWEvent & \multirow{2}{*}{\multicolumn{3}{|c|}{ Connect Monsternsights and Setup Website Analyitics Learn More }} \\
\hline og Media & & & \\
\hline LI Pages & \multirow{2}{*}{\multicolumn{2}{|c|}{$\begin{array}{l}\text { Christmas sale - 60\% off the MetaSlider Add-on Pack until December 25th } \\
\text { With discount code: XMAS2021 } \underline{\text { eetit now - }}\end{array}$}} & Dismiss \\
\hline O wP Staging & & & \\
\hline Comments 204 & \multicolumn{2}{|l|}{ Hola! Would you like to receive automatic updates and unlock premium support? Please a adtivate your copy of WPBakery Page Builder. } & $\theta$ \\
\hline
\end{tabular}

Gambar 5. Halaman Dashboard 


\section{Cara Edit Teks Paragraph Pada Page (Misalnya Teks Paragraph di Tentang FCJ)}

1. Melakukan Login terlebih dahulu, setelah login, di kiri atas ada tulisan sarasvita.com dan tekan visit site.

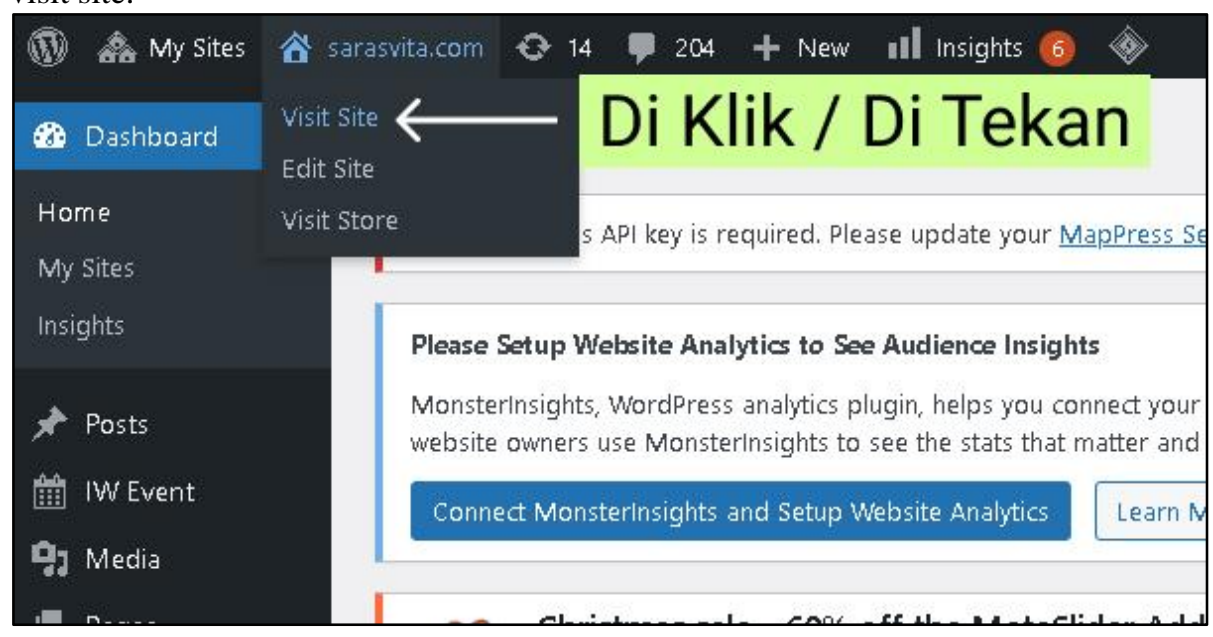

Gambar 6. Tampilan Web dari sisi Developer

2. Jika berhasil maka tampilan akan menjadi seperti ini.

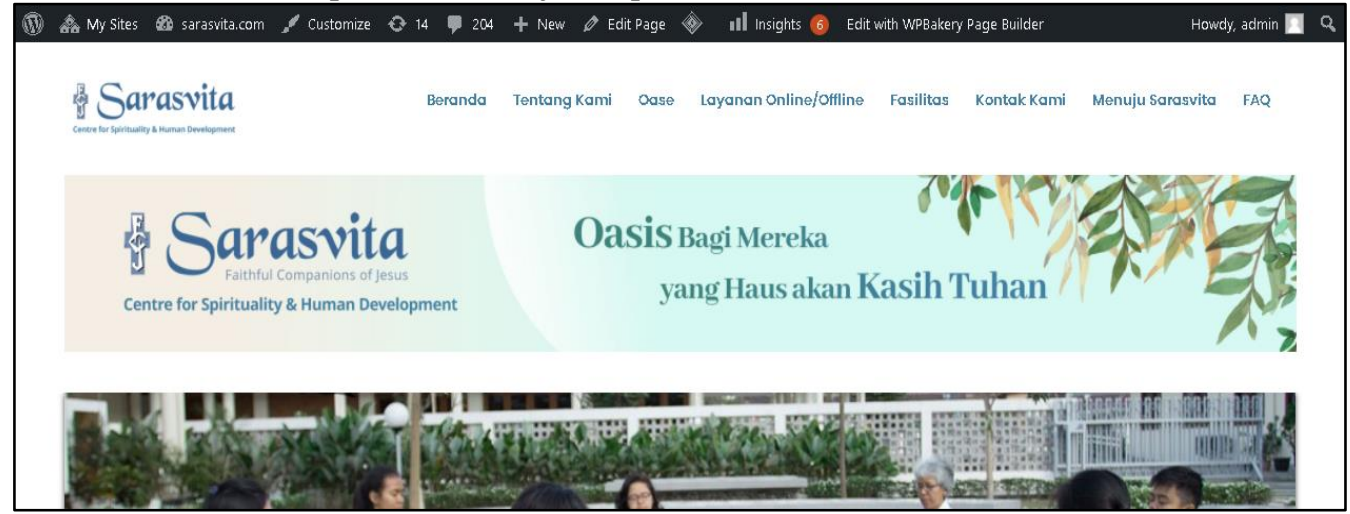

Gambar 7. Tampilan Web dari Sisi Developer

3. Jika ingin mengedit page di bagian "Tentang FCJ" maka, ke "Tentang Kami" baru klik "FCJ"

\section{Beranda}


4. Jika sudah masuk maka tampilannya menjadi seperti ini.

Tentang FCJ
Sarasvita
Madeleine d'Houet pada tahun 1820 di Perancis. Pada tahun 1805 , beberapa bulan sebelum melahirkan anak
lelakinya, Eugene, suaminya meninggal dunia. Pada tahun 1817, Marie Madeleine memasukkan anaknya ke

\section{Gambar 9. Tampilan Edit Page dari WPBakery}

5. Scroll ke bawah. Baru tekan "Edit with WPBakery Page Builder".

\begin{tabular}{|c|}
\hline 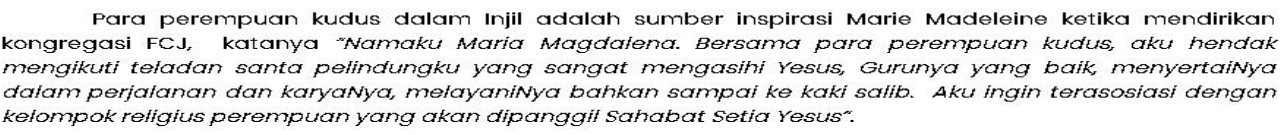 \\
\hline $\begin{array}{l}\text { Sesuai dengan namanya, Sahabat setia Yesus, kami memiliki kerinduan menjadi rekan kerja Yesus } \\
\text { dalam karyaNya di bumi ini. Saat ini para suster FCJ berkerja di Eropa, Kanada, Australia, dan Asia. Biara } \\
\text { induk (generalat) FCJ terletak di London - Inggris. }\end{array}$ \\
\hline Di Indonesia FCJ hadir mulai tahun 1987 dan saat ini berkarya di Yogya dan Ende. \\
\hline $\begin{array}{l}\text { Edit Edit with wpBakery page Builder } \longleftarrow \text { Di Klik } \\
\text { ARTIKEL TERBARU }\end{array}$ \\
\hline
\end{tabular}

Gambar 10. Tampilan Edit Konten

6. Jika berhasil tampilannya menjadi seperti ini.

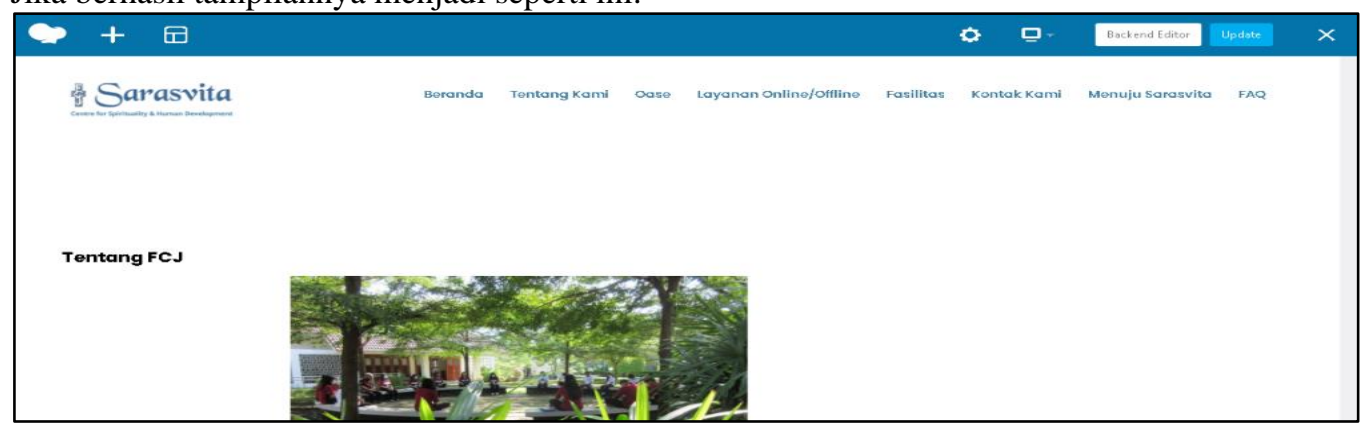

Gambar 11. Tampilan Tentang FCJ setelah diperbaiki 
7. Setelah itu mousenya di arahkan ke bawah. Dan tekan icon pensil di bagian text block, kotak yang warna hijau.

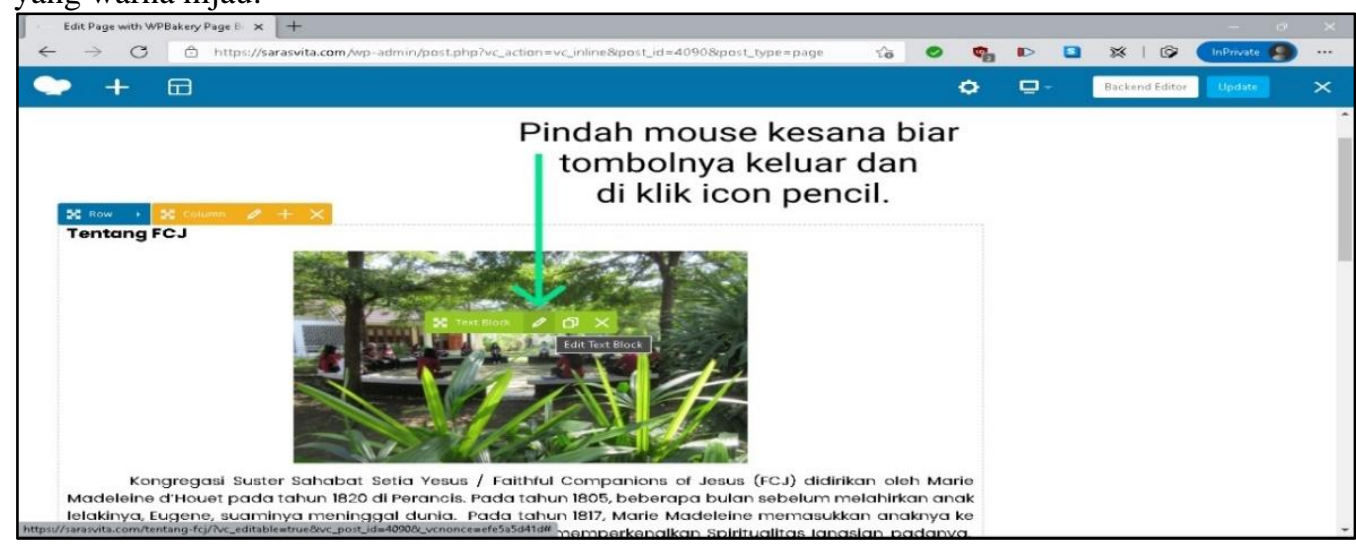

Gambar 12. Tampilan Text Editor dari Konten

8. Jika berhasil maka akan muncul tampilan ini.

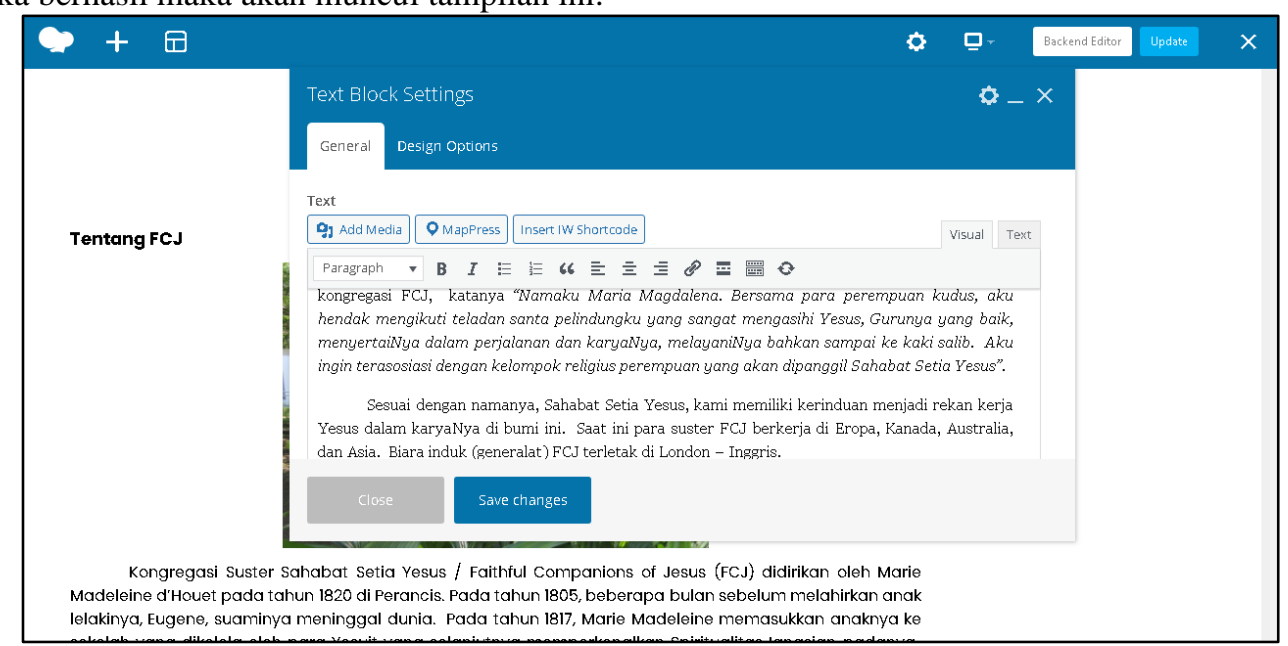

Gambar 13. Tampilan TextEditor

9. Untuk mengganti teks bisa di klik di bagian kotak tulisan disana.

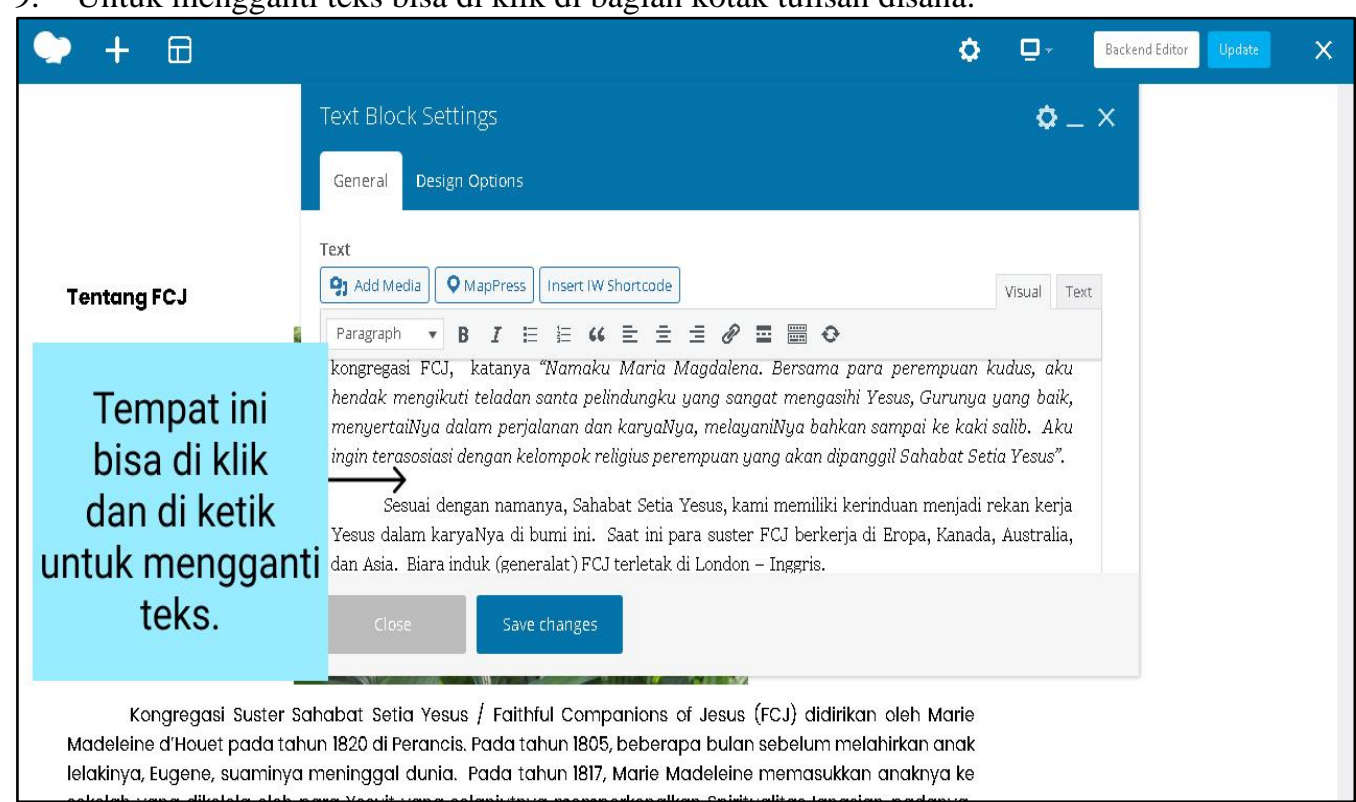

Gambar 14. Tampilan Edit Text 
10. Jika ingin memberi bold atau italics, dapat memakai fitur di menu yang disediakan.

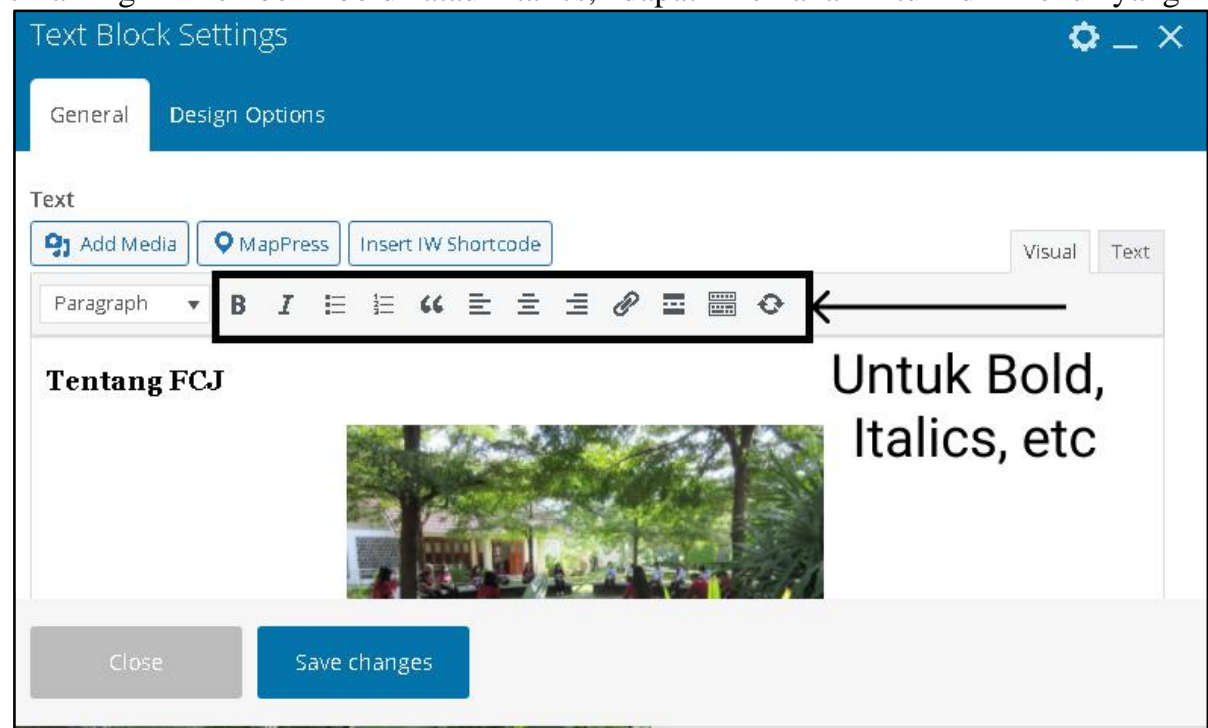

Gambar 16. Tampilan Font Editor

\section{Cara Ganti Gambar Pada Page (Misalnya Gambar di Tentang FCJ)}

1. Login ke sarasvita wp admin terlebih dahulu.

2. Setelah login ke page "Tentang FCJ".

3. Scroll ke paling bawah pilih "Edit with WPBakery Page Builder".

4. Pilih "Edit Text Block".

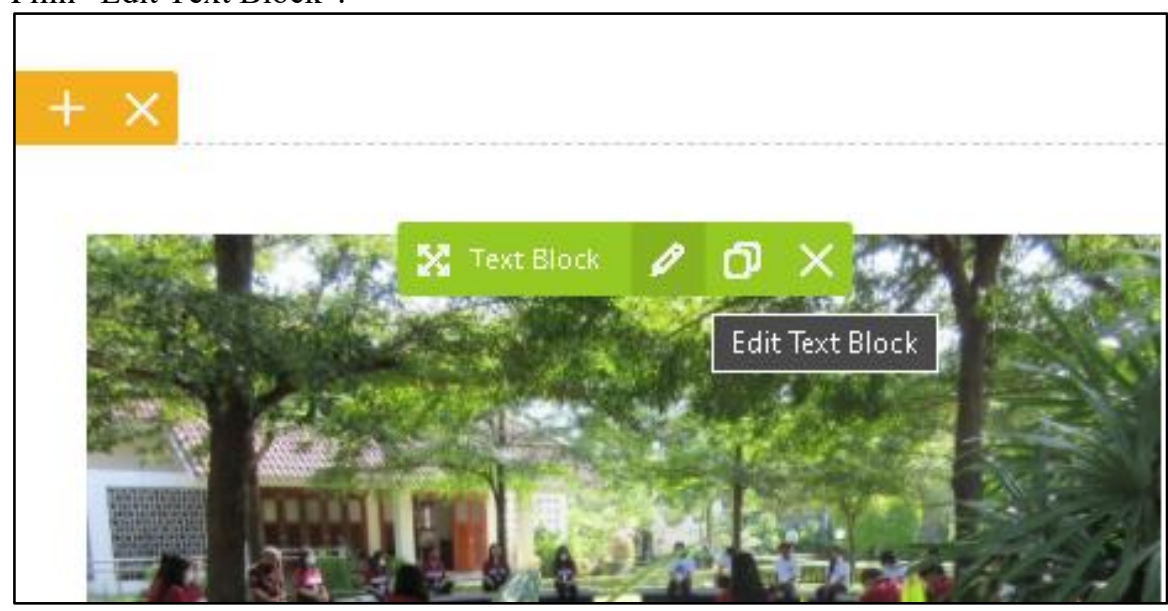

Gambar 16. Tampilan Ganti Gambar

5. Jika sudah berhasil maka akan muncul tampilan ini.

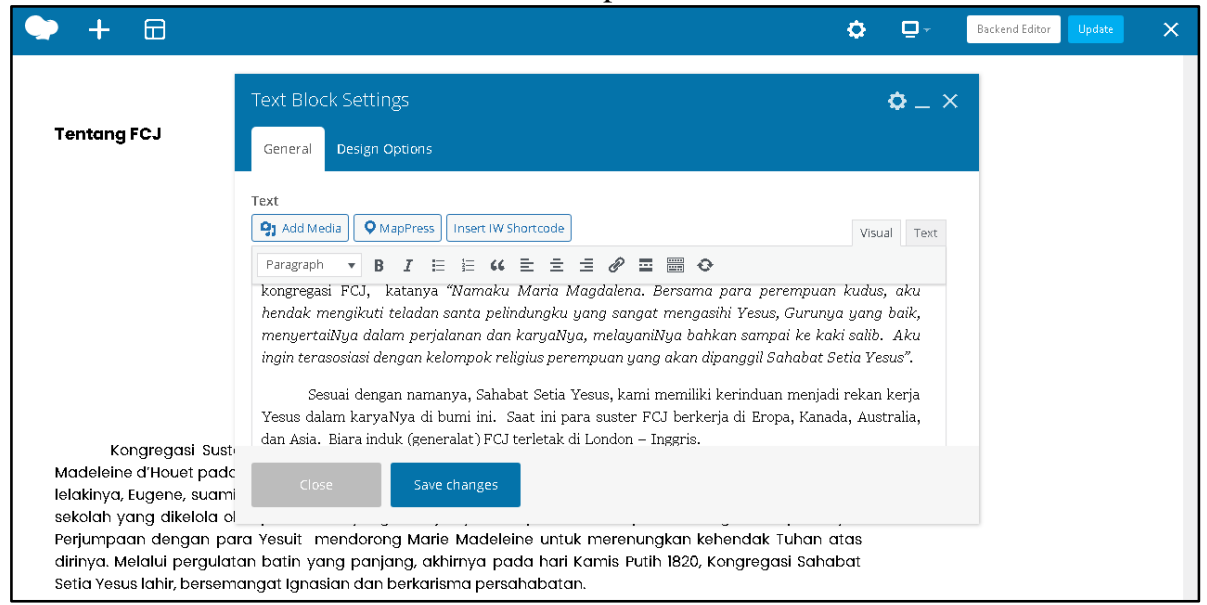

Gambar 17. Tampilan Text Block Settings 
6. Baru klik tombol "Text".

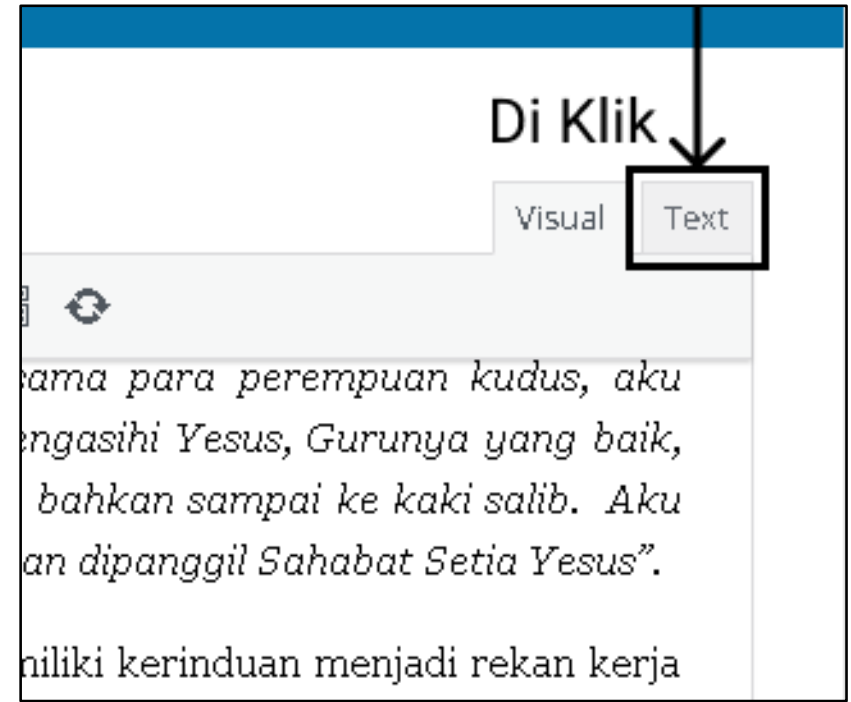

Gambar 18. Tab Text

7. Jika berhasil maka tampilannya seperti ini.

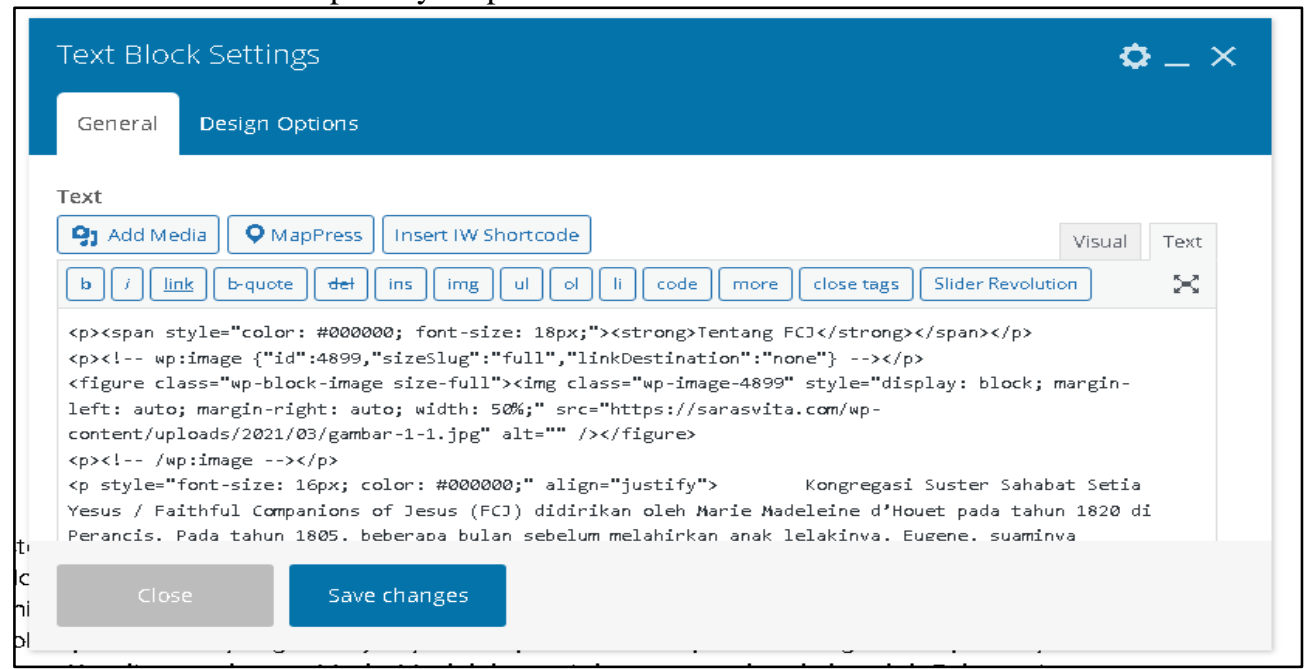

Gambar 19. Tab General Edit Content

8. Baru perhatikan tulisan " $\mathrm{src}=$ "https://sarasvita.com/wp-content/uploads/2021/03/gambar-1-

1.jpg".

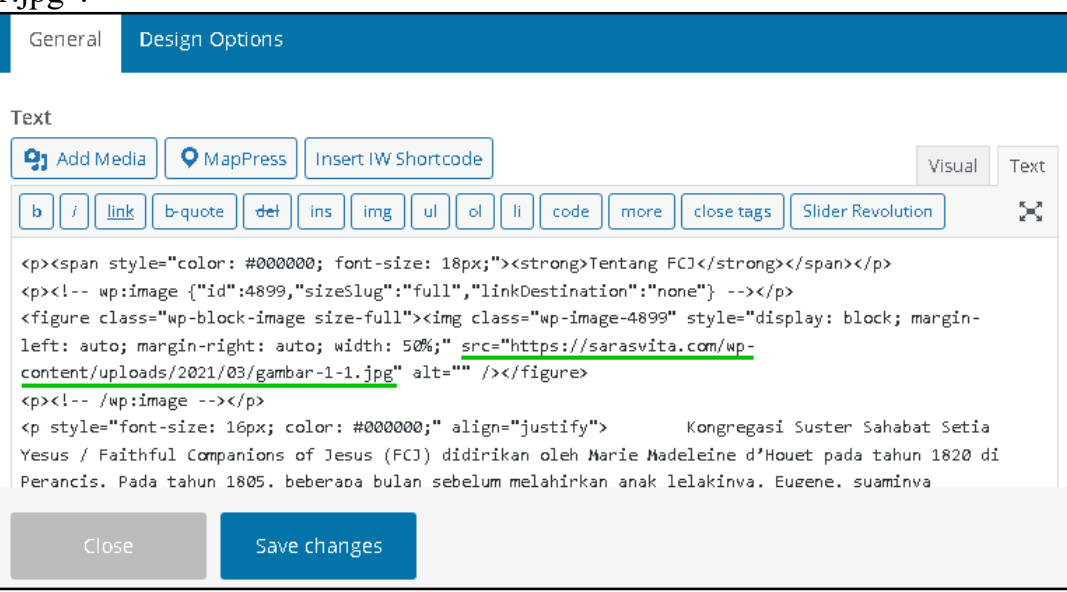

Gambar 20. Tag HTML Ganti Gambar 
9. Dimana link tersebut merupakan alamat gambar yang ingin digunakan. Sehingga, jika ingin mengganti gambar dengan yang lain, silahkan di ganti link tersebut menjadi link gambar lainnya. Contoh dari "src="https://sarasvita.com/wp-content/uploads/2021/03/gambar-1-1.jpg"" menjadi "src="https://sarasvita.com/wp-content/uploads/2021/03/gambar-8-150x150.jpg"”.

\section{Cara Tambah Gambar / Insert Image (Misalnya di Tentang FCJ)}

1. Login ke WP Admin dan pilih page yang diinginkan untuk ditambah gambar.

2. Edit with WPBakery.

3. Baru edit textblock.

4. Jika berhasil tampilannya seperti ini.

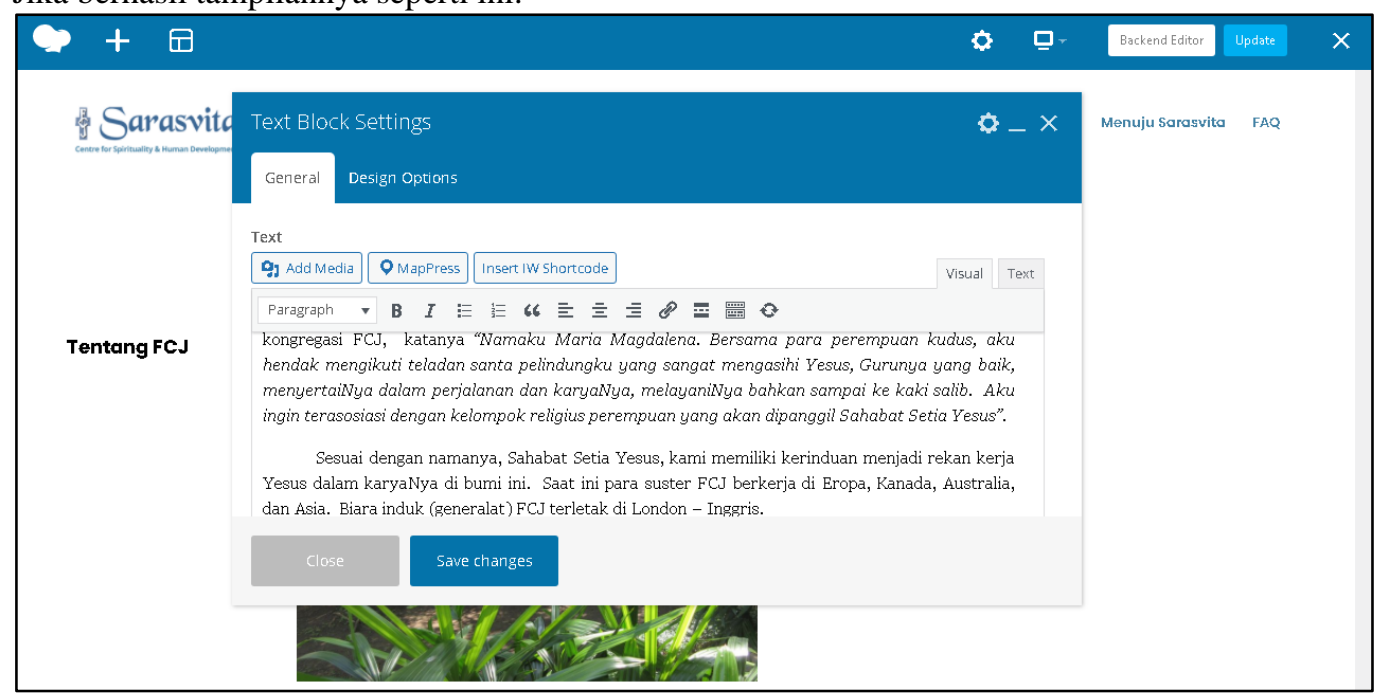

Gambar 28. Tampilan Insert Media

5. Pada bagian ini pilih "Text".

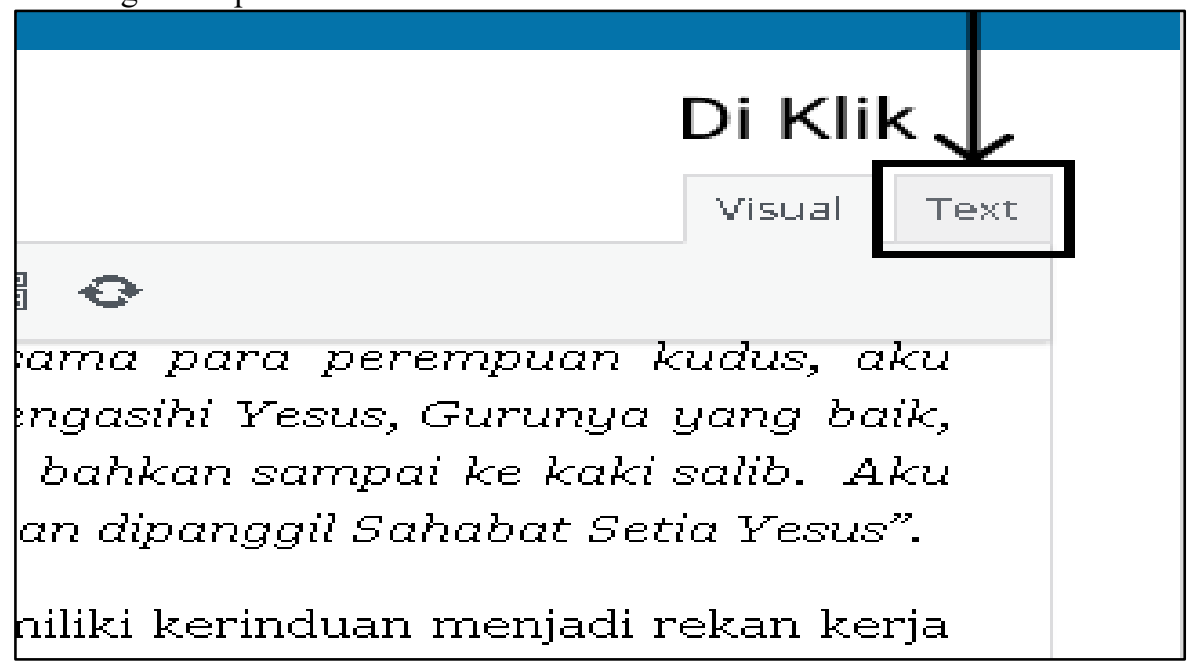

Gambar 29. Tampilan Ubah Web dengan Tag HTML

6. Setelah ke bagian "Text”, ke paling atas. Atau di ke bagian text yang ingin ditaruh gambar. Taruh tulisan ini " $<$ img $\operatorname{src}=" "$ " $>$ ". Tanda kutip nya dibuang. Jadi yang dicopy / diketik hanya ini saja. <img src="" />

7. Setelah di taruh <img src="" /> nya, maka tinggal di isi link alamat gambar yang diinginkan di bagian ini. <img src=" https://upload.wikimedia.org/wikipedia/commons/1/10/Ulstein-Church2020.jpg " / . 


\section{Cara Edit Page (WPBakery)}

1. Pilih page yang ingin di edit, scroll ke bawah dan tekan "Edit with WPBakery Page Builder". Contoh page yang saya pakai adalah "Tentang FCJ".

Perjumpaan dengan para Yesuit mendorong Marie Madeleine untuk merenungkan kehendak Tuhan atas
dirinya. Melalui pergulatan batin yang panjang, akhirnya pada hari Kamis Putih 1820 , Kongregasi Sahabat
Setia Yesus lahir, bersemangat Ignasian dan berkarisma persahabatan.
Para perempuan kudus dalam Injil adalah sumber inspirasi Marie Madeleine ketika mendirikan
kongregasi FCJ, katanya "Namaku Maria Magdafena. Bersama para perempuan kudus, aku hendak
mengikuti teladan santa pelindungku yang sangat mengasihi Yesus, Gurunya yang baik, menyertaiNya
dafam perjalanan dan karyaNya, melayaniNya bahkan sampai ke kaki safib. Aku ingin terasosiasi dengan
kelompok religius perempuan yang akan dipanggil Sahabat Setia Yesus".
Sesuai dengan namanya, Sahabat Setia Yesus, kami memiliki kerinduan menjadi rekan kerja Yesus
dalam karyaNya di bumi ini. Saat ini para suster FCJ berkerja di Eropa, Kanada, Australia, dan Asia. Biara
induk (generalat) FCJ terletak di London - Inggris.
Di Indonesia FCJ hadir mulai tahun 1987 dan saat ini berkarya di Yogya dan Ende.
Edit Edit with wPBakery Page Builder $\longleftarrow$ Di Klik
ARTIKEL TERBARU

Gambar 30. Edit page dengan WPBakery Page Builder

2. Jika sudah berhasil maka hasilnya akan seperti ini.

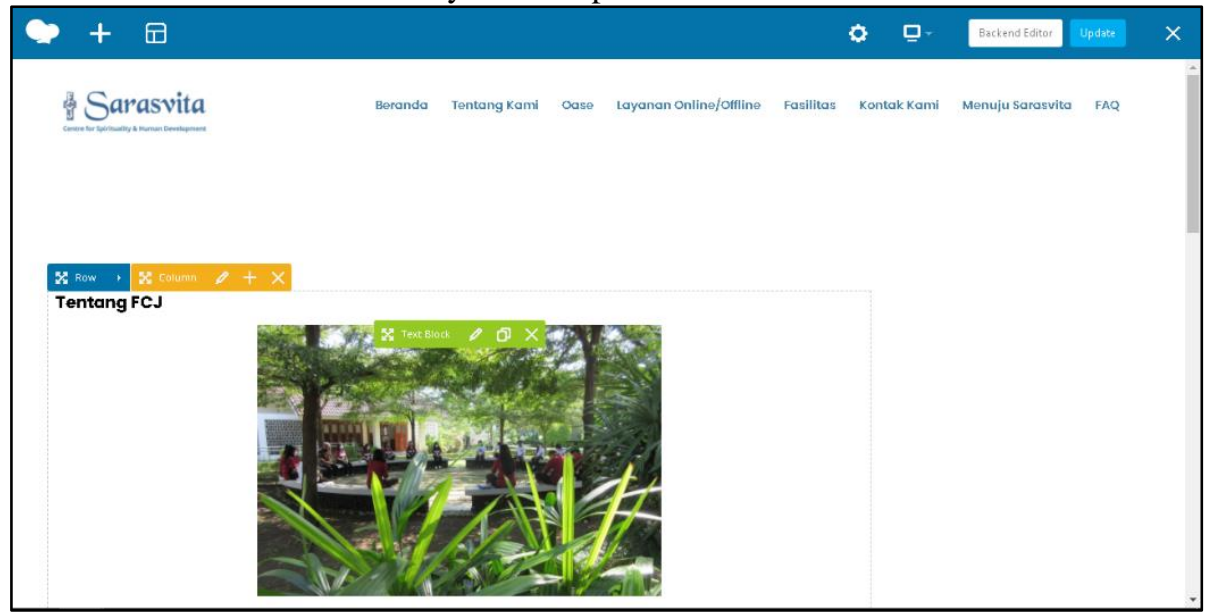

Gambar 31. Tampilan awal Edit Page

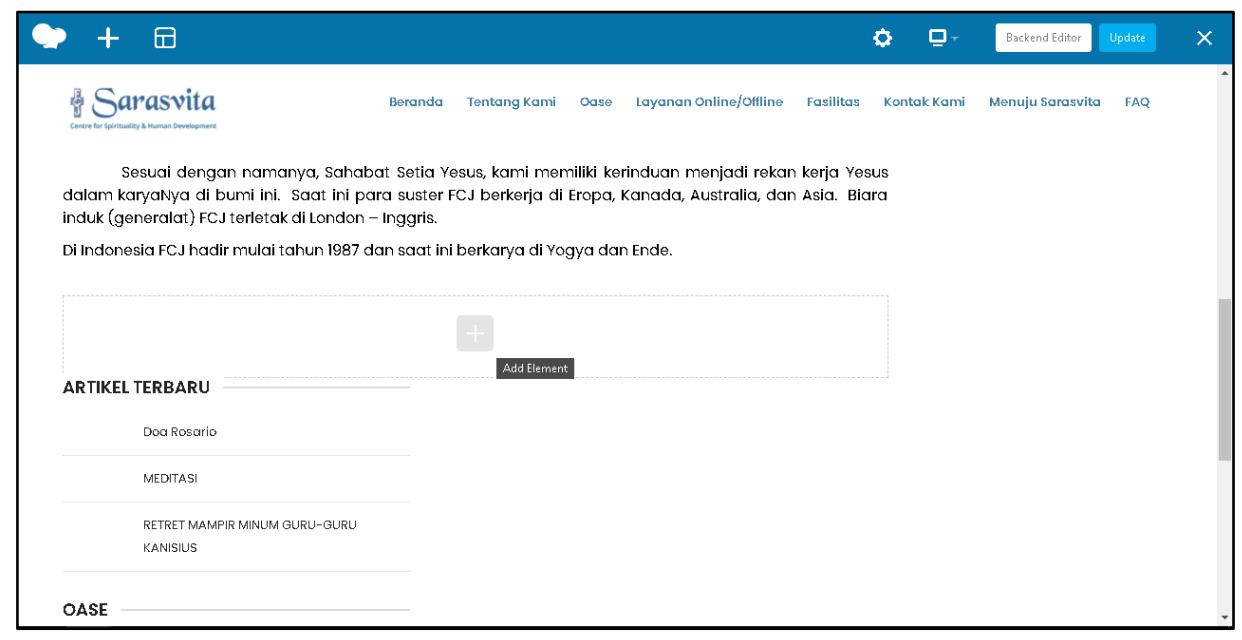

Gambar 32. Tampilan Awal Add Element. 
3. Tombol ini bisa diklik untuk menambah barang.

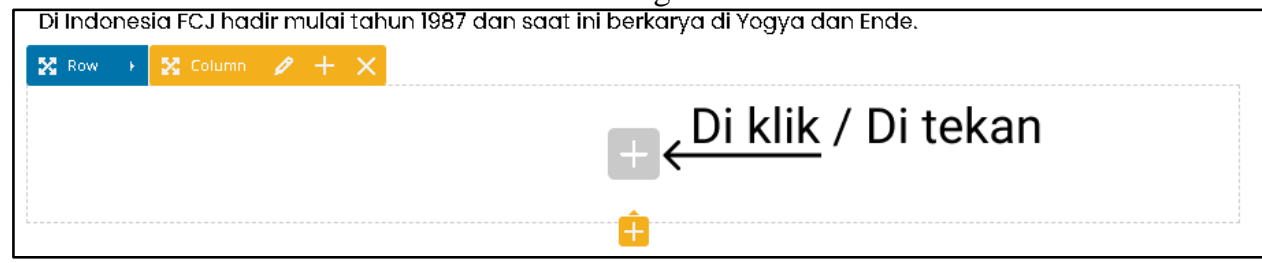

Gambar 33. Tampilan Langkah - Langkah Add Element.

4. Setelah tombol tersebut ditekan maka hasilnya seperti ini.

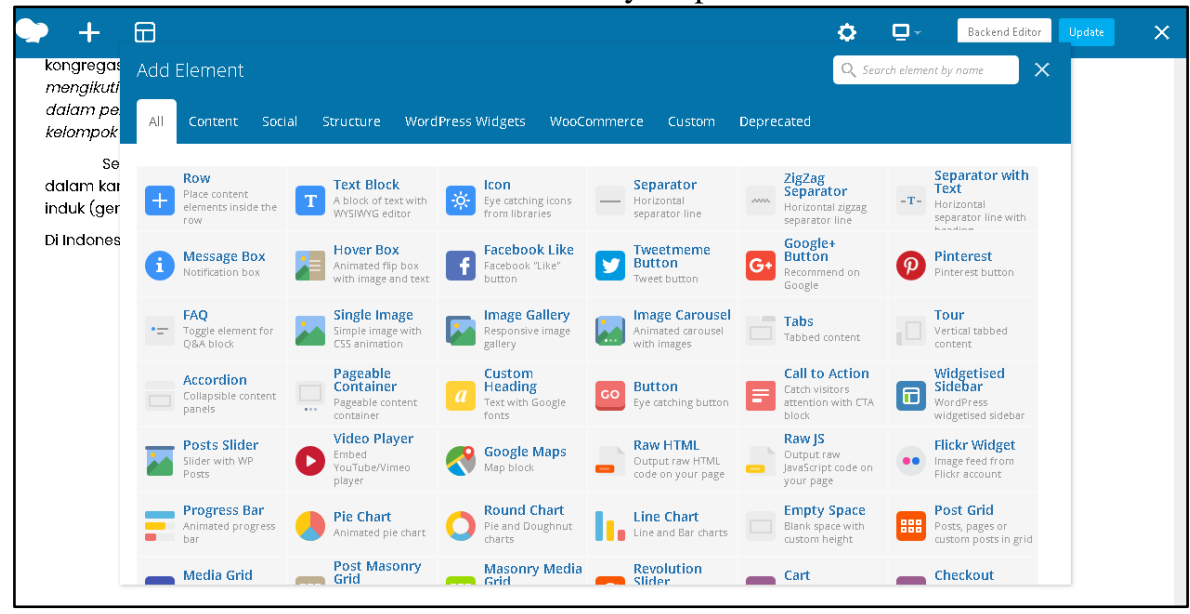

Gambar 34. Element untuk Content

5. Dimana icon tersebut bisa di klik sesuai keinginan. Misalnya jika ingin menambahkan misalnya video dari youtube, maka bisa pilih "Video Player". Jika ingin misalnya menambah text maka bisa pakai "Text Block."

\section{Cara Untuk Menambah Page Baru}

1. Login ke WP Admin terlebih dahulu. Setelah itu pilih menu pages. Di kiri. Di bagian ini.

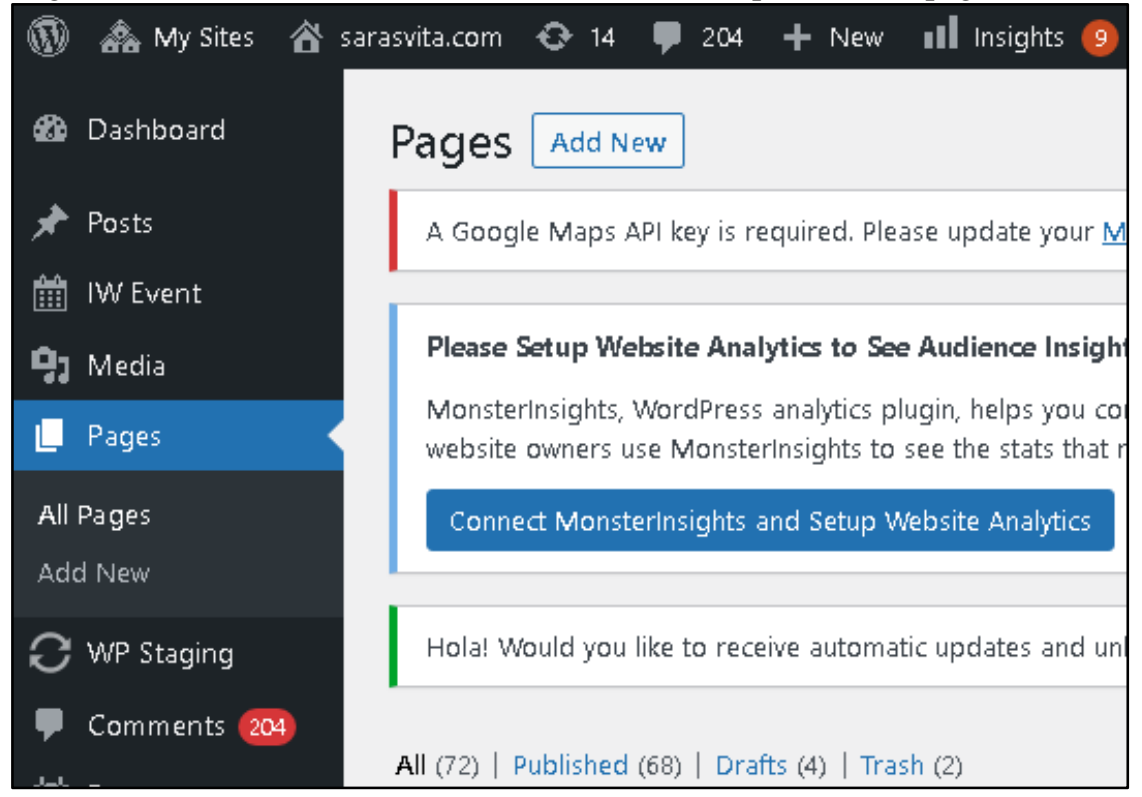

Gambar 35. Add New Page 
2. Setelah itu tekan "Add New". Ada 2 tombol "Add New". Cukup pilih salah satu.Tombol "Add New" berada di bagian ini.

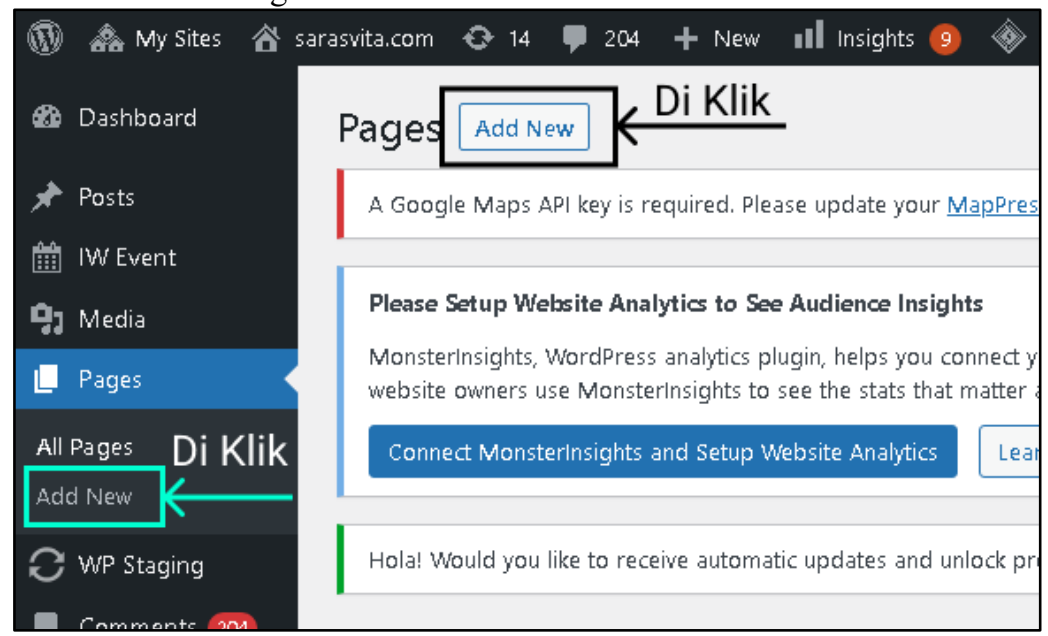

Gambar 35. Langkah - Langkah Add New Page

3. Jika sudah berhasil maka tampilannya seperti ini.

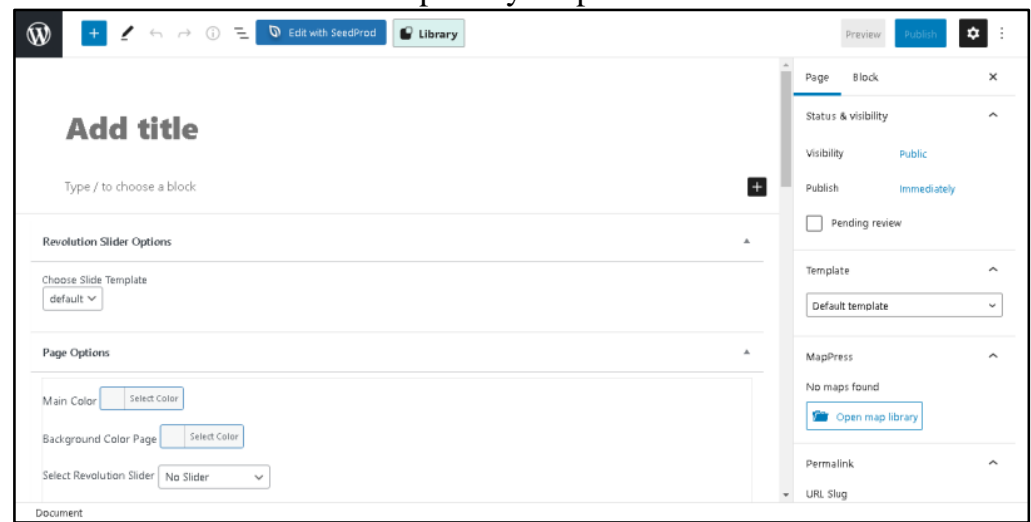

Gambar 36. Tampilan Page Baru

4. Baru isi sesuai kebutuhan. Jika sudah selesai tekan publish.

\section{Hasil}

Perbaikan pada website Rumah RetRet Sarasvita telah berhasil dilakukan sesuai dengan permintaan dan arahan dari Staff Rumah RetRet Sarasvita. Perbaikan yang didapatkan mampu memberikan dampak bagi visitor untuk mengetahui rumah RetRet Sarasvita lebih dalam lagi dan event - event yang akan dilakukan. Website yang telah diperbaiki memberikan informasi yang cukup akurat dan up-to-date hal ini dikarenakan tim Rumah RetRet sudah mampu melakukan perbaikan sendiri.

\section{PENUTUP}

\section{Simpulan}

1. Dengan terus berkembangnya teknologi maka media sosial dari sebuah institusi harus mampu menyesuaikan diri, baik dari segi sosial ataupun dari segi teknisnya.

2. Proses penyesuaian sebuah media sosial bukan merupakan hal mudah karena terlalu banyak standar framework perangkat lunak yang sudah ada di pasaran yang dapat digunakan secara gratis sehingga cara mengembangkan media sosial antara sebuah framework menjadi bertolak belakang dengan framework lainnya selama berlangsungnya proses pengembangan.

\section{Saran}

Untuk pengembangan di masa mendatang disarankan untuk memiliki tim pengembangan back-end hanya dengan fitur-fitur dasar seperti CSS, JavaScript dan Native PHP agar tidak terlalu banyak standar framework yang digunkan dalam sebuah website sehingga perawatan website di masa mendatang menjadi lebih mudah. 


\section{E. DAFTAR PUSTAKA}

Berthon, P. R., Pitt, L. F., Plangger K., Shapiro D.. 2012. Marketing meets Web 2.0, social media, and creative consumers: Implications for international marketing strategy

Morissan \& Moriarty, 2007, Periklanan Komunikasi Pemasaran Terpadu.

https://katadata.co.id/intan/berita/61ee4467db13b/internet-adalah-jaringan-komputer-ini-pengertian-dansejarahnya

https://www.w3.org/ W3C Consortium

https://www.w3schools.com W3C Schoool

https://www.dicoding.com/blog/ngoding-web-dinamis-atau-statis/ 